\title{
TELAAH FENOMENOLOGIS PATRIMONIALISME BUDAYA POLITIK TERHADAP KONFLIK SUNNÎ-SHÎ'AH MADURA
}

\author{
Jatim \\ Sekolah Tinggi Ilmu Ushuluddin al-Mujtama‘ Pamekasan, Indonesia \\ E-mail: jamis.mr@gmail.com
}

\begin{abstract}
The article attempts to discover the violence conflict between the Sunnî and the Shî‘ah Muslim communities in Karang Gayam and Blu'uran, Sampang, Madura. The conflict between the two communities has occurred since 2005 to 2013, and has escalated from one event to another. The conflict has caused the expulsion of Shî'ah people out of Madura island to the refugee's flats of Puspa Agro Sidoarjo on June 20, 2013. Based on the evidences found, the research is intended to study the phenomenon using phenomenological and patrimonial-political-cultural approaches. The study finds that the conflict itself has been caused by a set of hatred discourses and accusation of being heretic, which have been intensely propagated by the local religious elites, i.e. kiai against the Shîah community led by Tajul Muluk. Moreover, the conflict escalation was, among other, due mainly to the strength of patronage relations of the kiais to infiltrate their hegemony and produce the mass to commit violent actions. Incongruously, the power of patronage has been also benefited by the government and many political elites to maintain their political electability and votes. As a result, the government seems to be reluctant to show a firm attitude by enforcing the existing rules to deal with the issue.
\end{abstract}

Keywords: Conflict; Shî‘ah; Sunnî; phenomenology; patrimonialism.

\section{Pendahuluan}

Agama datang ke dunia dengan misi untuk keselamatan umat manusia. Semua agama pada dasarnya membawa pesan keselamatan, kedamaian, keadilan, kearifan dan cinta kasih. Namun dalam perkembangannya, agama seringkali dilibatkan dalam konflik atau peperangan, walaupun itu bukan misi dari agama, tetapi karena adanya 
faktor-faktor dari para pemeluk agama yang dibawa ke ranah agama hingga terjadi konflik. Ketika agama sudah berfusi dengan berbagai aspek kehidupan lain, maka tidak jarang agama menjadi alat legitimasi kekerasan dan menjadi kekuatan yang dominan dalam membangkitkan identitas emosional dibandingkan dengan identitas sosial lainnya.

Munculnya konflik keagamaan tidak bisa digeneralisir sebagai kesalahan pemeluk agama dalam memahami ajarannya. Konflik dan kekerasan yang terjadi terkadang terurai dari berbagai kepentingan yang melingkupi para pemeluk agama, seperti kepentingan ekonomi, politik, dan kekuasaan. Jika menelusuri embrio konflik keagamaan di tubuh umat Islam yang bernuansa politik dan kekuasaan, bisa dilacak pada masa akhir kekhalifahan 'Uthmân b. 'Affân yang kemudian membuncah pada masa kekhalifahan 'Alî b. Abî Tâalib.

Konfik-konflik sosial yang bernuansa agama di Indonesia di antranya adalah konflik yang terjadi di Poso Sulawesi Tengah pada 17 April 2000 antara umat Kristen dan umat Islam, ${ }^{1}$ peristiwa kerusuhan di Ambon yang terjadi pada hari raya Idul Fitri 19-24 Januari 1999 antara umat Islam dan Kristen, ${ }^{2}$ penyerangan terhadap kelompok Ahmadiyah di Cikeusik, Pandeglang Banten pada hari Minggu 6 Februari 2011, ${ }^{3}$ kerusuhan Temanggung Jawa Tengah, 8 Februari 2011, yang berawal dari ketidakpuasan massa pada keputusan pengadilan negeri Temanggung atas kasus penistaan agama dengan terdakwah Antonius Richmond Bawenga, ${ }^{4}$ dan konflik yang masih hangat di benak masyarakat Indonesia adalah konflik Sunnî-Shî‘ah di Sampang Madura yang telah terjadi sejak 2004 dan memuncak pada 26 Agustus 2012, dengan pembakaran 37 rumah pengikut Shî‘ah dan berujung pada pengusiran pengikut Shî‘ah di Sampang Madura. ${ }^{5}$

Sebagaimana yang digambarkan oleh media massa, bahwa konflik di Sampang berawal dari persoalan keluaraga yang merembet menjadi

\footnotetext{
${ }^{1}$ Levi Silalahi, "Poso, Enam Tahun Dirundung Duka", Tempo (12 Mei 2004).

2 Sudjangi, "Konflik Sosial Bernuansa Agama: Studi Kasus Kerusuhan di Ambon", dalam http:/ / balitbangdiklat.kemenag.go.id. (Departemen Agama RI 2002).

${ }^{3}$ Hertanto Soebijoto, "Inilah Kronologi Cikeusik Berdarah itu”, Kompas (26 April 2011).

4 Regina Rukmorini, "Kerusuhan Temanggung, Tiga Gereja Dirusak Massa", Kompas (8 Februari 2011).
}

5 Dini Mawuntyas, "Bagaimana Kronologi Syiah Masuk Sampang?”, dalam http://www. tempo.co, Surabaya (2 September 2012). 
konflik ideologi, sehingga terjadilah konflik teologis Sunnî-Shî‘ah. ${ }^{6}$ Konflik yang berujung dengan perilaku anarkisme ini merupakan puncak dari ketegangan dua aliran yang berbeda. Pihak Sunnî ${ }^{7}$ melihat paham $\mathrm{Sh}^{6}{ }^{6} \mathrm{~h}^{8}$ sebagai gerakan keagamaan yang berlawanan dengan keyakinan yang dianut oleh kelompok Sunnî, sehingga perbedaan aliran ini menimbulkan resistensi yang berujung pada konflik kekerasan.

Banyaknya konflik sosial-keagamaan yang terjadi di Indonesia, termasuk kasus di Sampang ini, tentu sangat memprihatinkan. Tidak saja karena dianggap mengganggu stabilitas negara dan keamanan nasional, tetapi hal itu juga mencederai realitas keberagaman Indonesia sebagai bangsa yang sudah memilih dasar Pancasila dan Undang-undang Dasar 1945 yang berdiri di atas Bhineka Tunggal Eka. Selain itu, peristiwa konflik yang terjadi turut menambah sejarah kelam hubungan antaragama, serta kehidupan berbangsa dengan asas toleransi dan kerukunan di Indonesia. Padahal semua agama selalu menyerukan umatnya untuk berbuat baik kepada sesama, lingkungan dan terutama kepada Tuhannya.

Konflik di Sampang, yang oleh media dianggap sebagai konflik antardua paham, yaitu Sunnî dan Shî‘ah yang menggambarkan tentang hubungan disharmoni antara kedua aliran tersebut. Sunnî dalam konteks Madura identik dengan warga Nahdhatul Ulama (NU) yang merupakan mayoritas di Sampang, bahkan di Madura. Kebanyakan masyarakat Madura merupakan penganut NU, sehingga paham ini menjadi paham terbesar yang diyakini oleh masyarakat Madura, khususnya masyarakat Sampang. Konflik intraagama itu merupakan prahara yang telah

${ }^{6}$ Mulyono, Wawancara, Sampang, 20 April 2014.

${ }^{7}$ Sunnî (Ahl al-Sunnah wa al-Jamâ‘ah) dalam pemahaman orang Madura secara umum adalah Nahdlatul Ulama, karena mayoritas warga Madura menganut paham keagamaan NU.

8 Ada perbedaan mendasar antara paham Sunnî dan Shî‘ah. Perbedaan paham tersebut terletak pada rukun Islam dan rukun Iman pada kedua aliran paham tersebut. Rukun Islam dalam keyakinan Sunnî, yaitu, shahâdatayn, salat, zakat, puasa dan haji. Sedangkan dalam pemahaman Shî'ah rukun Islam, yaitu: salat, puasa, zakat, haji dan wilâyah atau imâmah (kepemimpinan). Rukun iman dari kedua paham ini juga ada perbedaan. Dalam keyakinan Sunnî, rukun iman, yaitu; iman kepada Allah, iman kepada malaikat-Nya, iman kepada kitab-kitab-Nya, iman kepada rasul-Nya, iman kepada hari akhir serta iman kepada qada dan qadar. Adapun dalam pemahaman Shî‘ah rukun iman, yaitu; tauhid, nubunwah, imâmah, al-'adl dan al-ma'âd. Tim Penulis Majlis Ulama Indonesia (MUI), Mengenal dan Mewaspadai Penyimpangan Syiah di Indonesia (Jakarta: FORMAS, 2013), 85. 
mereduksi harmoni sosial di kalangan masyarakat Sampang dan masyarakat Madura secara umum, sehingga menimbulkan ketegangan sosial yang memanas dan pada gilirannya akan berujung pada penyuburan benih-benih konflik di tengah-tengah masyarakat.

Aksi kekerasan atasnama agama atau paham tertentu yang terjadi di Madura merupakan fakta menakutkan tentang masa depan kerukunan umat beragama di Madura yang selama ini dikenal sangat kuat dalam memegang kerukunan antarsesama dalam bingkai keragaman. Akan tetapi, semenjak munculnya konflik Sunnî-Shî‘ah di Sampang, terlepas apapun motifnya, hal itu telah menggerogoti konstruk kerukunan yang telah lama terbangun di Madura dan telah menjadi budaya.

Oleh sebab itu, disharmoni yang mulai tampak ini perlu dicarikan model solusi konflik yang tepat, agar konflik tidak terjadi lagi. Madura dalam konteks social, budaya dan politik masih kental dengan sistem kepemimpinan patrimonial, di mana para kiai memiliki dominasi publik karena patron-klien yang kuat di masyarakat tersebut. Di sini, peran tokoh masyarakat — salah satunya kiai-tetap menjadi figur utama untuk mereduksi benih konflik yang mulai tumbuh sejak konflik Sunnî-Shî‘ah terjadi. Patron kiai terbentuk karena perannya sebagai elite agama dan elite politik, sehingga buah pikirannya mudah untuk disepakati. ${ }^{9}$ Artinya, kiai memiliki ruang gerak dalam dimensi profetik dan profan dalam struktur sosial masyarakat.

Etnik Madura memiliki kekhasan kultural, hal ini terlihat dalam struktur kepemimpinan Madura yang akrab disebut bhuppa' bhabbhu', ghuru, rato (ayah-ibu, guru, dan pemerintah). Model kepemimpinan semacam ini orang tua, guru dan pemerintah adalah patron yang sudah terbentuk secara kuat. Bagi masyarakat Madura, kehidupan ini tidak akan mempunyai makna sosio-kultural dan religiositas, bila tidak berpedoman pada tiga trilogi kuasa tersebut. Orang tua bagi orang Madura, dimaknai sebagai representasi dari institusi tertinggi di keluarga. Figur guru atau kiai merupakan representasi dari kepemimpinan pada dimensi ukhrawi (profetik). Raja atau pemerintah mewakili representasi dari kepemimpinan pada dimensi duniawi (profan)..$^{10}$.

9 Abdul Chalik, "Kiai dan Kekuasaan Sosial dalam Masyarakat Madura", Jurnal Paramedia, Vol. 10, No. 1 (2010).

10 A. Latief Wiyata, Carok: Konflik Kekerasan dan Harga Diri Orang Madura (Yogyakarta: LKiS, 2002), 50. 
Konflik Sunnî-Shî‘ah yang telah melibatkan dua dari tiga struktur patron kepemimpinan di Madura, kiai dan pemerintah sebagaimana diberitakan dan diwacanakan dalam ranah publik, menarik untuk diselidiki dan diurai kebenarannya dari perspektif ilmiah. Kertas kerja ini menjadi upaya ilmiah untuk merunut secara komprehensif tentang konflik Sunnî-Shî‘ah di Karang Gayam tersebut. Sekilas peristiwa ini membenarkan hipotesa bahwa sebuah masyarakat dengan sistem dan tata nilai tertentu yang menjadi pedoman hidup bersama akan terusik oleh unsur-unsur baru yang mencoba masuk ke dalamnya, sehingga konflik menjadi sebuah keniscayaan. Hipotesa ini bisa berlaku pada apapun, kapanpun dan di mana pun dalam cakupan dimensional yang luas. Pada kasus ini, yang terlihat ajaran Shî'ah sebagai sesuatu yang baru itu.

\section{Narasi Konflik dari Hulu ke Hilir}

1. Konstruk Sosial-Budaya

Kabupaten Sampang adalah salah satu dari empat Kabupaten yang ada di pulau Madura. Secara geografis, Kabupaten Sampang terletak di antara $113^{\circ} 08-113^{0} 39$ Bujur Timur dan 06 05-07013 Lintang Selatan. Wilayah Kabupaten Sampang berupa daratan dan hanya terdapat satu pulau yang terpisah dari daratan, yaitu pulau Mandangin atau biasa disebut pulau Kambing. Pulau ini, berjarak kurang lebih 2 Mil, dari arah selatan kota Sampang. Wilayah Kabupaten Sampang, di sebelah Utara berbatasan dengan laut Jawa, sebelah Timur berbatasan dengan Kabupaten Pamekasan dan di sebelah Selatan berbatasan dengan selat Madura, sedangkan sebelah Barat berbatasan dengan Kabupaten Bangkalan. Kabupaten Sampang terbagi menjadi 14 Kecamatan dan 186 Kelurahan atau Desa, dengan luas wilayah 1.233,33 $\mathrm{Km}^{2}$. Adapun jumlah penduduk Kabupaten Sampang, menurut hasil sensus penduduk (SP) tahun 2010, berjumlah 877.772 jiwa, yang terdiri dari laki-laki 427.896 jiwa dan perempuan 449.876 jiwa.

Sampang secara ekologis seperti halnya Madura secara umum, yaitu konturnya berupa tegalan dengan tanah yang tandus, gersang dan tidak produktif untuk pertanian. Kondisi ini diperburuk pula oleh curah hujun yang sangat rendah, membuat para petani Sampang dan Madura secara umum menghasilkan produk pertanian yang serba terbatas. Kondisi ini secara langsung menciptakan kemiskinan di kalangan warga desa, tak terkecuali Desa Karang Gayam dan Blu'uran, Sampang Madura. Lahan pertanian yang tidak memberikan keuntungan ekonomis disertai 
peningkatan jumlah penduduk yang cukup tinggi dari tahun ke tahun menciptakan problem ekonomis yang cukup akut. Kondisi ini tak jarang membuat masyarakat Sampang dan Madura secara umum mengambil pilihan untuk migrasi sebagai solusi yang dianggap strategis guna memperbaiki masa depannya. ${ }^{11}$

Dari sisi keagamaan, masyarakat di Sampang termasuk penganut kegamaan yang taat. Agama Islam yang dipeluk mayoritas penduduk menjadi bagian dari martabat dan harga diri. Tidak jarang jika ada gangguan penodaan agama, maka akan disamakan dengan melecehkan harga diri dan identitas Madura yang dapat menimbulkan resistansi atau konfrontasi fisik, seperti carok. Bagi orang Madura, rasa dilecehkan akan muncul apabila suatu stimulan dari luar mengakibatkan perasaan malu bagi dirinya. Perasaan ini dalam bahasa Madura disebut maloh atau todus, rasa dilecehkan ini yang sering menjadi pemicu tindak kekerasan. Hal ini dapat dilihat pada idiom yang populer di kalangan masyarakat Madura, ango'an poteya tolang etembang poteya matah (lebih baik putih tulang ketimbang putih mata). Artinya, lebih baik mati dari pada hidup menanggung perasaan malu. ${ }^{12}$

Dari sisi sosio-kultural, seperti halnya Madura secara umum bahwa struktur kehidupan di Sampang, baik politik maupun sosial-keagamaan didominasi oleh elite lokal, yaitu kiai (pemimpin agama), blater ${ }^{13}$ (jagoan atau bajingan) dan klebun (kepala desa). Blater, kiai, dan klebun (kepala desa), ketiganya memiliki kekuatan dalam memproduksi wacana, kultur, tradisi, dan jaringan kekuasaan di tengah masyarakat. Di antara ketiganya, kiai dan blater yang paling memegang kendali sosio-kultural. Rozaki mengistilahkan kiai dan blater sebagai rezim kembar (twin-regimes) dalam membangun kuasa di tengah masyarakat. Blater sebagai penggerak dan pengelola mesin-mesin pergerakan, sehingga banyak media dan ritus

11 Huub De Jonge, Garam, Kekerasan, dan Aduan Sapi: Esai-esai tentang Orang Madura dan Kebudayaan Madura (Yogyakarta: LKiS, 2011), 77-80.

12 Wiyata, Carok: Konflik Kekerasan, 170-172.

13 Blater adalah sosok orang kuat di Madura, baik secara fisik maupun magic Mereka biasanya dikenal memiliki ilmu kebal dan ilmu bela diri. Sebutan 'blater,' menunjukkan pada seseorang yang perilakunya cenderung mengarah pada tindakan kriminal, seperti berjudi, mencuri dan lain-lain. Orang blater biasanya cenderung memiliki sifat angko (pemberani). Abdur Rozaki, "The Social Origins and Political Power of Blaters (thugs) in Madura", dalam http://kyotoreview.org/wp-content/uploads/Abdur-RozakiENG.pdf. (11 Desember 2009), 2; Wiyata, Carok: Konflik Kekerasan, 94. 
sosial yang digunakan blater untuk menghegemoni masyarakat, seperti acara $r e m o b^{14}$ dan kerapan sapi. Sedangkan kiai dalam kapasitasnya sebagai ahli agama berperan menafsirkan wacana agama, sehingga mampu menghegemoni masyarakat dari struktur terdalam di ruang batin, pikiran dan perilaku masyarakat. Antara dua elite ini saling terjalin relasi di banyak sisi kehidupan bermasyarakat.

2. Bibit Ideologi Shî‘ ah di Madura

Penduduk desa Karang Gayam mulai berkenalan dengan ajaran Islam Shî'ah sekitar tahun 1980-an. Paham ini dikenalkan oleh Kiai Makmun b. Ahmad Nawawi. Pada mulanya ia hanya mengajarkan kepada keluarga dan putra-putrinya saja. Awal mulanya, Kiai Makmun tidak pernah merasa puas dengan ilmu yang telah diperoleh, sehingga ia terus menggali dan mempelajari literatur kitab-kitab Islam klasik yang mengantarkannya bersinggungan dengan paham Shî‘ah. Kiai Makmun alumnus pondok pesantren Sidogiri dan pernah nyantri di pondok pesantren Kiai Abdullah Faqih, Malang. Kemudian Kiai Makmun menikah dengan Khairu Ummah dan dikarunia delapan anak, yaitu: Iklil Milal, Tajul Muluk, Roisul Hukama, Fatimah Azzahrah, Ummu Hani, Ummu Kulsum, Budur Makzuzah, dan Ahmad Miftahul Huda.

Menurut keterangan Iklil Milal, ajaran abl al-bayt memang sudah dikenalkan oleh Kiai Makmun (ayahnya) di kalangan keluarga sejak tinggal di Batu Ampar, ${ }^{15}$ tetapi masyarakat umum tidak mengetahui akan hal itu karena diajarkan di kalangan tertentu saja. Keyakinan Kiai Makmun terhadap paham Shî'ah Semakin kuat ketika mendengar keberhasilan Ayatullah Ali Khomaeni dalam memimpin revolusi Iran pada tahun 1979. Milal melanjutkan, ayah pernah ngirim surat ke Iran. Setelah itu, ayah mendapatkan kiriman buku-buku dari Iran di antaranya buku

\footnotetext{
14 Remob adalah acara yang dilengkapi hiburan sandur. Sandur adalah suatu jenis kesenian tradisional semacam ludruk yang dimeriahkan oleh penari (tandak) laki-laki dengan diiringi gamelan. Dengan adanya hiburan sandur, maka seorang blater dapat menunjukkan kapasitasnya, sebagai seorang jagoan. Ia menari dengan jenis tarian tertentu sesuai dengan pilihannya. Remoh pada dasarnya, merupakan suatu pesta tempat berkumpulnya para orang jago atau blater. Wiyata, Carok: Konflik Kekerasan, 72-73.

15 Batu Ampar adalah sebuah makam yang cukup terkenal di Madura, yang biasa diziarahi banyak orang, mulai dari orang Madura itu sendiri serta orang luar Madura, termasuk Jawa.
} 
perbandingan mazhab yang lima, serta surat kabar, buletin tentang Shîah dan poster-poster bergambar Khomaeni. ${ }^{16}$

Keberhasilan ulama Iran era Khomaeni dalam menumbangkan tradisi kepemimpinan otoriter dan monarki di Iran menjadi sumber inspirasi bagi Kiai Makmun untuk mempelajari ajaran Islam Shî‘ah secara mendalam. Hal ini ada benarnya, sebagaimana apa yang dinyatakan oleh Fuad Jabali, bahwa keberhasilan revolusi Iran tahun 1979 yang dipimpin Ali Khomaeni telah membuat banyak kalangan umat Islam tertarik mempelajari Shî‘ah, termasuk anak-anak muda Indonesia. Banyak dari mereka yang dari peristiwa ini tertarik membaca literatur-literatur Shî‘ah. Peristiwa itu menjadi momentum historis bagi penyebaran ajaran Islam Shî‘ah ke seluruh penjuru dunia, termasuk Indonesia. ${ }^{17}$

Sementara masyarakat Madura adalah penganut model kepemimpinan patronase atau patron klien sebagaimana yang dipopulerkan Max Weber, termasuk di Sampang. Model kepemimpin semacam ini lebih dominan terbentuk oleh karisma dan pengaruh kultural, daripada mempertimbangkan kapasitas dan integritas perorangan, atau model kepemimpinan berdasarkan pertimbangan keturunan (gen). Kiai sebagai elite dalam struktur sosial masyarakat Madura cenderung diwariskan secara turun-temurun dan hierarkis. Kondisi kepemimpinan model ini membuat Kiai Makmun gelisah, sebab ia hanya akan membangun otokrasi kekuasaan yang bersifat premordial, tanpa ada semangat egaliterian dan mempedulikan nasib kalangan kecil. Kegelisahan itu semakin menguat ketika melihat realitas kehidupan masyarakat sekitar yang serba tertinggal, dari mulai bidang pendidikan, ekonomi sampai politik. Ia berkesimpulan bahwa kepemimpinan yang lumrah itu hanya akan menguntungkan bagi pribadi dan golongan.

Protes sosio-kultural dari Kiai Makmun terhadap dominasi elite di atas nampak dalam penuturan Iklil. Ayah saya selalu berpesan, utamakan masyarakat dari pada keluarga. Kalau sikap kiai tetap seperti ini, maka pada suatu saat nanti tidak akan lama lagi lebih berharga kaleng minuman dari pada kiai, sebab kaleng minuman masib dicari orang, sedangkan kiai tidak dibutubkan oleh masyarakat. Menurut Iklil, ayahnya ingin keluar dari pola hidup kiai, yang hanya menjadikan masyarakat sebagai klien atau pelayan. Ia selalu mengajarkan pada putra-putrinya, bahwa kiai dan masyarakat

\footnotetext{
${ }^{16}$ Iklil Milal, Wawancara, Sidoarjo 12 April 2014.

${ }^{17}$ Fuad Jabali, "Sengketa Iman", dalam Mata Najwa Metro-TV (5 September 2013).
} 
berkedudukan sama dalam strata sosial, tidak ada sekat atau jarak yang membedakan. ${ }^{18}$ Refleksi Kiai Makmun tidak berlebihan, pada faktanya pengaruh kiai sangat mengakar dalam kehidupan masyarakat Madura. Kiai dan keluarganya mendapat perlakuan yang sangat istimewa bahkan cenderung di-dewa-kan. Pemahaman yang mainstream adalah kiai mempunyai hak otoritatif untuk menafsirkan wilayah keagamaan, yang kemudian berpengaruh terhadap kehidupan sosial-budaya masyarakat Madura.

Kiai Makmun berusaha keluar dari sistem kepemimpinan dalam masyarakat yang hanya mengandalkan karisma dari faktor keturunan, sementara mengenyampingkan kapabilitas dan integritas. Sistem semacam ini menjadikan ketidakberdayaan masyarakat, karena ketergantungan mereka pada sosok kiai. Padahal semua masyarakat memiliki hak yang sama di bidang sosial, pendidikan, poltik dan ekonomi dalam konteks bernegara. Visi ini bagi Kiai Makmun menemukan tambatan ideologisnya, ketika ia mengenal kiprah Khomaeni yang berhasil memimpin revolusi di Iran. Secara tidak langsung hal ini menuntunnya untuk lebih mendalami ajaran Shî‘ah yang identik dengan ideologi Khomaeni. Visinya kemudian dipertegas dengan menyiapkan kader-kader dari keluarganya, maka pada tahun 1983 ia mengirimkan putra-putrinya ke Yayasan Pesantren Islam (YAPI) di Bangil, Pasuruan. Pesantren ini dikenal umum sebagai pusat Shî‘ah Ja'farîyah di Jawa Timur. Putra-putri Kiai Makmun yang dikirim ke YAPI adalah Tajul Muluk, Roisul Hukama dan putrinya, Ummu Hani. ${ }^{19}$

Pada tahun 1991, selepas lulus SMP YAPI, Tajul kembali ke Sampang. Tahun 1993, Tajul berangkat ke Arab Saudi untuk bekerja. Seiring dengan keterbatasan ekonomi, Tajul terus bertahan di Arab Saudi sebagai pekerja. Pada tahun 1999, Tajul pulang dari Arab Saudi dan menetap di Karang Gayam, Sampang Madura. Pada saat itu, paham Shî'ah juga belum diajarkan secara terbuka terhadap masyarakat sekitar, namun hanya di kalangan keluarga. Kiai Makmun juga tidak pernah mengharuskan bagi keluarganya untuk mengikuti paham ia anut dan yakini, seperti kepada istrinya, ibu Ummah sampai sekarang tetap menganut paham Sunnî dan putra-putrinya juga tidak semuanya menganut paham Shî‘ah. Di antara putra-putrinya yang menganut paham

18 Iklil Milal, W awancara, Sidoarjo, 12 April 2014.

19 Ibid. 
Shî‘ah adalah Iklil Milal, Tajul Muluk, Roisul Hukama, Ummu Hani dan sisanya; Fatimah Azzahrah, Ummu Kulsum, Budur Makzuzah dan Ahmad Miftahul Huda menganut paham Sunni. ${ }^{20} \mathrm{Hal}$ ini, menunjukkan kepemimpinan Kiai Makmun sangat demokratis dalam mendidik dan membangun kehidupan dalam keluarga dan masyarakat.

3. Percikan Api Konflik yang Mulai Berkobar

Sepulang Tajul dari Arab Saudi pada tahun1999, ia mulai mengambil alih otoritas dakwah ayahnya, Kiai Makmun. Ia akrab dipanggil oleh masyarakat setempat dengan sebutan $\mathrm{R} a \mathrm{Tajul}$. $\mathrm{R} a$ adalah paggilan yang umum digunakan di Madura untuk menyebut anak keturunan kiai. Karismanya dengan cepat terbentuk sesuai dengan pola budaya Madura, karena ia keturunan kiai dan silsilahnya sampai kepada Batu Ampar yang dipercayai punya keramat oleh masyarakat setempat, bahkan dari luar Madura.

Pada tahun 2004, Tajul mendirikan sebuah surau (musala) atas permintaan masyarakat sekitar sebagai pusat aktivitas dakwah. Di surau mungil inilah, diadakan aktivitas-aktivitas keagamaan seperti salat berjemaah, tahlilan, pembacaan surah Yâsin dan salawat setiap malam Jumat. Dalam acara mingguan yang diadakan setiap malam Jumat itu, setiap jemaah ditarik iuran dua ribu rupiah. Dari hasil iuran ini, dana yang terkumpul digunakan untuk membantu biaya pendidikan anak-anak jemaah, pengobatan bagi yang tidak mampu, perbaikan masjid, dan sebagainya. Ini awal mula paham Shî‘ah menjadi komunitas di Karang Gayam, Sampang Madura. ${ }^{21}$

Sejak saat itu, syiar keislaman yang beraliran Shî‘ ah berkembang pesat di bawah kepemimpinan Tajul. Pola dakwah Tajul berbeda dengan sang ayah, Kiai Makmun yang mengajarkan paham Shî‘ah secara diam-diam (taqîyah), sementara Tajul mengajarkan dan mendakwahkan Shî‘ah secara terbuka. Menurut Cholis Waidi, ketertarikan masyarakat kepada Tajul karena pola dakwah dan sikapnya yang egaliter, supel, ringan tangan, cekatan dan tidak menerima honor (cabisan) di setiap ceramahnya, serta berbaur dengan masyarakat, sehingga membuatnya menjadi kiai muda yang dihormati di Desa Karang Gayam saat itu. Selang beberapa waktu,

${ }^{20}$ Ibid.
21 Ibid. 
ratusan warga di Desa Karang Gayam dan Bulu'uran telah menjadi pengikut Shî‘ah dan menjadi murid setia Tajul. ${ }^{22}$

Perkembangan dakwah Shî‘ah yang melaju pesat melahirkan respons yang luar biasa dari para kiai NU. Di antaranya yang dilakukan oleh Kiai Ali Karrar Shinhaji ${ }^{23}$ dari pondok pesantren Darut Tauhid, Lenteng Proppo Pamekasan, Madura. Ia sangat keberatan terhadap aktivitas dakwah yang dilakukan Tajul. Dalam perspektif Kiai Ali, aliran Shî‘ah merupakan mazhab dalam Islam yang salah dan sesat. Tak hanya Kiai Ali, para kiai lain di Madura secara mayoritas merespons dengan cara yang sama yang melahirkan keberatan atas aktivitas dakwah Tajul. Namun, pada saat itu, tahun 2004 para kiai tidak secara terbuka menentang dakwah yang dilakukan Tajul, karena masih menaruh rasa hormat terhadap Kiai Makmun. Penentangan kiai Sunnî semakin menguat terhadap aktivitas dakwah yang dilakukan Tajul sejak tahun 2006 setelah sang ayah, Kiai Makmun meninggal dunia. ${ }^{24}$

\section{Kronologi Ekses yang Berujung Chaos}

Ekses antara kelompok Sunnî yang mayoritas di Madura dan Shî‘ah yang marginal menemukan momen-momennya sejak 2006. Peristiwaperistiwa yang menyebabkan semakin runcingnya kontestasi dakwah tidak sehat di antara dua kelompok sebenarnya dimulai dari hal-hal kecil dan sangat personal sampai menjadi intimidasi masif dengan pelibatan pihak otoritatif di Madura. Dalam perspektif penulis dapat diuraikan dan dipilahkan menurut motifnya sebagai berikut:

1. Kontestasi Dakwah dan Pelabelan Sesat

Pertengahan tahun 2005, Kiai Ali Karrar Shinhaji mengadakan pengajian di Desa Karang Gayam yang dihadiri oleh ribuan masyarakat dan para kiai sekecamatan Omben, Sampang Madura. Pengajian akbar ini sengaja diadakan untuk menentang keberadaan komunitas Muslim Shî‘ah yang dipimpin Tajul, walaupun tidak secara tegas mengatakan aliran Shî‘ah sesat. Tapi, menggunakan kata sindiran dengan mengatakan, hatihati di lingkungan ini sudah ada paham yang menyimpang. Sejak itu, di kalangan masyarakat umum di wilayah Kecamatan Omben, tersiar kabar,

${ }^{22}$ Cholis Waidi, Wawancara, Sampang 5 Maret 2014.

${ }^{23}$ Kerabat dari Kiai Makmun, ayah Tajul Muluk.

24 Dini Mawuntyas, "Bagaimana Kronologi Syiah Masuk Sampang?", dalam http:/ /www.tempo.co/ Surabaya (2 September 2012). 
bahwa di Desa Karang Gayam telah berkembang aliran sesat, yaitu paham keagamaan yang beraliran Shî‘ ah. ${ }^{25}$

Manuver-manuver syiar kebenciaan dan penyesatan kelompok Sunnî terhadap kelompok Shî‘ah yang dipimpin Tajul semakin intens dilakukan. Pada tanggal 20 Februari 2006, diadakan pertemuan kiai se-Madura atas inisiatif Kiai Ali Karrar. Pertemuan itu juga dihadiri Bupati Sampang, H. Fadilah Budiono dan Kepala Depag Sampang, Imron Rosyidi. Perkumpulan yang diadakan di rumah $\mathrm{H}$. Sya 'bi menghadirkan pimpinan kelompok Shî‘ah, Tajul, dengan agenda klarifikasi tuduhan sesat ajaran Islam Shî'ah yang didakwahkan. Pada rapat itu, Tajul datang beserta kawan-kawannya dengan membawa kitab-kitab rujukan untuk dijelaskan kepada para kiai yang hadir saat itu. Namun para kiai tidak mau mendengarkan penjelasan Tajul. Para kiai hanya meminta Tajul kembali ke Sunnî dan melarangnya melakukan aktivitas dakwah Shî‘ah. Tajul diberi waktu seminggu untuk menjawab hasil keputusan musyawarah para kiai itu.

Pada tanggal 26 Februari 2006, sebagai kelanjutan dari pertemuan pada 20 Februari 2006. Pertemuan ini dipimpin Kiai Abdul Wahhab Adnan bersama ketua MUI Sampang, Mubassyir dan Kapolsek Omben. Pertemuan kali ini diadakan di Masjid Landeko' Karang Gayam tempat kediaman kakek Tajul, Kiai Nawawi. Pertemuan itu berusaha menghadirkan Tajul dan ia pun berkenan hadir waktu itu. Resminya, forum ini dinamakan Forum Musyawarah Ulama (FMU). Kala itu forum dihadiri oleh semua elemen yang juga hadir pada forum sebelumnya, yakni pada tanggal 20 Februari 2006. Mereka kembali hadir untuk menyaksikan dan mendengarkan jawaban Tajul tentang paham ajaran Islam Shî‘ah yang didakwahkan. Tajul menyatakan, paham Islam Shî‘ah yang diajarkannya tidak sesat dan merupakan salah satu mazhab yang diakui di dunia Islam. Oleh karena itu, ia tidak bersedia keluar dari paham Shî‘ah. Karena tidak mampu merubah sikap Tajul terhadap keyakinannya tentang paham Shî‘ah, maka kemudian FMU mengeluarkan putusan yang isinya sebagai berikut:

Mengajak pimpinan Shî‘ah Ja'farîyah, Tajul Muluk agar segera kembali ke jalan ahl al-Sunnah wa al-Jamâ'ah dan sesepuh terdahulu, untuk menghindari terjadinya bentrokan paham dan fisik di kalangan masyarakat awam yang sangat dikhawatirkan terjadi. Karena Tajul telah menolak

${ }^{25}$ Iklil Milal, W awancara, Sidoarjo, 12 April 2014. 
tawaran FMU tersebut, maka FMU tidak bertanggung jawab atas segala apa yang terjadi dan memasrahkan persoalan kepada yang berwajib. FMU menghimbau kepada Majlis Ulama Indonesia (MUI) di empat Kabupaten di Madura agar segera menyatakan fatwa tentang bahaya aliran-aliran sesat, termasuk aliran Shî̌ah yang meragukan keabsahan al-Qur'ân, keadilan sahabat Nabi, dan berlebihan dalam menghormati abl al-bayt (keluarga Nabi). ${ }^{26}$

Setelah keputusan FMU, pada 9 April 2007 saat bulan Maulid, Tajul mengajak masyarakat untuk mengadakan perayaan Maulid Nabi Muhammad yang disatukan di masjid di hari kelahiran Nabi, agar masyarakat yang tidak mampu bisa merasakan perayaan Maulid Nabi dengan tanpa terbebani. Tradisi ini sebelumnya diadakan secara bergiliran di tiap rumah dengan mengundang kiai atau ustaz, sehingga bagi mayarakat yang tidak mampu terpaksa mencari pinjaman uang ke tetangga yang lebih mampu dari sisi ekonomi, atau dengan menjual ternaknya dan ada juga yang menggadaikannya. Menurut Mulyono, musim Maulid Nabi itu menjadi musim panen para kiai dan ustaz, karena setiap rumah berlomba-lomba mengundang mereka, dan tentu harus diberi honor (cabisan), minimal 50 ribu. Hal semacam ini, menurutnya, sudah menjadi tradisi umum di Sampang, bukan hanya di Desa Karang Gayam dan Blu'uran.

Niat baik Tajul kandas, karena masyarakat sekitar telah terkontaminasi oleh fitnah-fitnah yang disebarkan oleh tokoh-tokoh agama yang fanatik dengan mengatakan ajaran Tajul menyesatkan, bahkan oleh masyarakat sekitar dianggap agama baru. Ketika tersiar Tajul juga akan mengadakan perayaan Maulid Nabi, ribuan massa dari beberapa desa datang dengan membawa beragam senjata seperti celurit dan pentungan. Mereka mengepung jalan masuk menuju Desa Karang Gayam dan melakukan penghadangan terhadap semua tamu undangan yang akan datang. Massa terus mengawasi dan memeriksa setiap kendaraan yang lewat. Untuk menghindari jatuhnya korban, sejumlah aparat dari Polres Sampang dan anggota TNI dikerahkan menjaga

26 Rusdi Mathari, "Mereka Sibuk Menghitung Langkah Ayam", dalam http://rusdimathari. wordpress.com/2012/08/27/mereka-sibuk-menghitung-langkahayam-reprtase-kasus-syiah-sampan g/. (27 Agustus 2012); Hasil laporan investigasi Kontras Surabaya, "Laporan Investigasi dan Pemantauan Kasus Syiah Sampang", dalam http://kontras.org/data/ Laporan\%20Investigasi $\%$ 20Syiah\%20di\%20Sampang.pdf. (Surabaya: Kontras, 2012), 4. 
keamanan di sekitar rumah Tajul. Acara Maulid tetap dilaksanakan, walaupun acara itu hanya dirayakan oleh jemaah Shı̂‘ah di sekitar kediaman Tajul dan santrinya, di bawah pengawasan dan penjagaan aparat keamanan. ${ }^{27}$

Setelah peristiwa penyerangan di atas, pada bulan Ramadhan 26 Oktober 2009 MUI Sampang bersama PCNU Sampang, ketua DPRD, kepala Depag, Bakesbangpol (Kepala Badan Kesatuan Bangsa dan Politik) dan para tokoh agama di Kabupaten Sampang mengadakan pertemuan untuk menyikapi dan mencarikan solusi terkait keberadaan paham Shî‘ah yang berkembang di Desa Karang Gayam dan Blu'uran. Pertemuan ini diadakan di Mapolres Sampang dan menghasilkan lima poin pernyataan yang harus ditandatangani Tajul di atas materai bersama elemen-elemen tokoh di atas. Surat bersama itu isinya, antara lain:

Pertama, Tajul tidak diperbolehkan lagi mengadakan ritual dan dakwah yang berkaitan dengan aliran Shî‘ah, karena telah meresahkan masyarakat. Kedua, Tajul bersedia untuk tidak melakukan ritual, dakwah, dan penyebaran aliran tersebut di Kabupaten Sampang. Ketiga, apabila tetap melaksanakan ritual dan dakwah maka saudara Tajul siap untuk diproses secara hukum yang berlaku. Keempat, pakem MUI, NU, dan LSM di Sampang akan selalu memonitor dan mengawasi aliran tersebut. Kelima, pakem MUI, NU, dan LSM siap untuk meredam gejolak masyarakat baik bersifat dialogis atau anarkis selama yang Tajul menaati kesepakatan di poin pertama dan kedua. ${ }^{28}$

Surat pernyataan bersama ini, menurut keterangan Iklil Milal dijadikan legitimasi bagi pihak-pihak yang anti-Shî‘ah di Karang Gayam dan Blu'uran untuk menyerang komunitas Muslim Shî‘ah. Dengan adanya surat pernyataan bersama ini, walaupun pada dasarnya penandatanganan Tajul karena terpaksa, bukan karena hendak menyetujui terhadap pernyataan surat bersama itu. Sebab surat itu dibuat hanya sepihak, tanpa sepengetahuan Tajul dan langsung disodorkan kepadanya untuk ditandatangani. Iklil menambahkan, masyarakat semakin menaruh kebencian dan berusaha melabelsesatkan komunitas Muslim Shî‘ah, karena merasa mempunyai legalitas pembenaran dari aksinya. ${ }^{29}$ Walaupun demikian, hal itu tidak dapat menghentikan dakwah

\footnotetext{
27 Mulyono, Wawancara, Sampang, 20 April 2014.

28 Adian Husaini (ed.), Kritik dan Solusi Syiah di Indonesia (Depok: Adabi Press, 2012), 30.

${ }^{29}$ Iklil Milal, W awancara, Sidoarjo, 12 April 2014.
} 
yang disyiarkan oleh Tajul. Sampai kemudian dibuatlah intimidasi baru dengan penandatanganan di atas surat pernyataan yang ditulis oleh Tajul sendiri yang berisi: (1) Tajul harus angkat kaki dari Madura, (2) Tidak menyebarkan pahamnya di kalangan masyarakat Madura, dan (3) Semua pengikutnya harus kembali bergabung dengan majelis taklim Sunnî (NU) untuk dapat dibina kembali.

Meskipun demikian, karena dasar kesepahaman ini berpihak kepada mainstream, maka hanya berlaku beberapa saat saja. Tajul menjalaninya selama setahun, terhitung dari tanggal ditandatanganinya surat pernyataan, yaitu pada tanggal 29 Juli 2011. Sedangkan biaya relokasi dibebankan kepada Pemkab Sampang dan Pemprov Jatim. ${ }^{30}$ Namun, menurut keterangan masyarakat, Tajul sering datang ke kediamannya, Desa Karang Gayam. Hal ini dibenarkan oleh Mulyono, Tajul Muluk memang sering pulang saya melihat sendiri. Tindakan Tajul pulang ke rumah menyulut kemarahan masyarakat karena dipersepsikan telah melanggar kesepakatan yang sudah ditandatangani oleh para kiai, sehingga tindakan Tajul dianggap menghina otoritas agama.

Menurut Mulyono, peristiwa pasca-29 Juli 2011, di mana Tajul tidak menunjukkan kepatuhannya terhadap pernyataannya, juga menjadi salah satu stimulan terjadinya aksi pembakaran rumah pada tanggal 29 Desember 2011. Aksi pembakaran itu menghanguskan tiga rumah, dimulai dari rumah Tajul, Iklil, dan yang terakhir rumah Ummu Hani, adik Tajul. ${ }^{31}$ Puncak dari ekses konflik antara Sunnî-Shî‘ah terjadi pada 26 Agustus 2012 setelah hari raya Idul Fitri, di mana dari ekses itu menyebabkan korban nyawa, Muhammad Hasyim alias Hammamah meninggal karena diserang oleh tiga orang dari kelompok anti-Shî‘ah dengan sabetan celurit yang mengenai perutnya, karena mencoba menenangkan situasi yang mulai memanas. Cerita selanjutnya, secara singkat berakhirlah komunitas Shî'ah harus mendiami ruko Puspa Agro, di Sidoarjo selama beberapa tahun kemudian.

2. Bermula dari Cinta, Menjadi Perseteruan Akidah

Hubungan kakak-adik, Tajul dan Rois berawal harmonis sebagaimana keluarga pada umumnya. Mereka bersama-sama menyebarkan paham Shî'ah antara tahun 2004-2008. Menurut Mulyono, di antara dua saudara

${ }^{30}$ Husaini (ed.), Kritik dan Solusi Syiah, 30-31; Pizaro, “Tajul Muluk dan Kisah Ingkar Janji Syiah Sampang”, dalam http://www.islampos.com (21 Juni 2013).

${ }^{31}$ Mulyono, W awancara, Sampang, 20 April 2014. 
itu, justru yang gencar mendakwahkan paham Shî‘ah pada masyarakat adalah Rois, karena ia berani mengadakan acara 'Ashurâ', tidak seperti Tajul yang tidak mengadakannya, karena takut akan menjadi fitnah di masyarakat. Bermula dari persaingan anak didik, benih perseteruan itu tumbuh. Pesantren milik Tajul sudah mulai berbentuk ke arah yang lebih mapan, karena memiliki pendidikan formal berupa Madrasah Ibtidaiyah meskipun belum mendapatkan surat izin dari dinas setempat, sementara Rois hanya mengajar ngaji di rumahnya.

Pada tahun 2008, anak-anak masyarakat sekitar yang sebelumnya belajar ngaji (belajar al-Qur'ân) dan agama di kediaman Rois, banyak yang ditarik oleh orang tuanya dan dipindahkan ke tempat Tajul untuk diasuh dan dididik, karena dianggap Rois tidak berhasil mendidik anak-anak mereka untuk bisa membaca al-Qur'ân dan memahami agama. Kecemburuan ini diindikasikan sebagai pemicu perseteruan yang lebih intens berikutnya. Terbukti, di kemudian hari, ketika Rois keluar dari paham Shî‘ah dan kembali ke Sunnî, ia menuding Tajul merebut muridnya. ${ }^{32}$ Padahal menurut Iklil, murid itu dipindahkan oleh orang tuanya sendiri bukan atas inisiatif Tajul. ${ }^{33}$

Menurut Tajul, kemarahan Rois kepada dirinya disebabkan oleh persoalan yang sepele, yaitu masalah perempuan. Suatu hari pada tahun 2009, Tajul didatangi Zainal yang juga pengikut Shî'ah, meminta tolong meminangkan Halimah, untuk putranya, Abdul Azis. Ia memenuhi permintaan tersebut dan pinangannya diterima oleh orang tua Halimah, Mad Badri. Sebelum itu, Rois telah meminta Halimah untuk membantu di rumah Rois, yang berjarak sekitar 500 meter sisi Utara kediaman Tajul. Ketika Rois mengetahui kejadian itu, ia tidak terima dan memanggil Mad Badri, Zainal, dan Abdul Aziz. Namun, sebelum memenuhi panggilan Rois, tiga orang tersebut meminta pertimbangan Tajul, apakah mereka harus memenuhi panggilan Rois atau tidak. ia menyarankan agar tidak memenuhi panggilan Rois dengan alasan Rois orangnya keras, tempramental dan mudah marah. Rois pun geram kepada Tajul, karena meminangkan Halimah untuk Aziz, tanpa sepengetahuan Rois. Rois pun mengaku sudah bertunangan dengan Halimah. Setelah pertunangan

\footnotetext{
32 Mulyono, W awancara, Sampang, 20 April 2014.

${ }^{33}$ Iklil Milal, W awancara, Sidoarjo, 12 April 2014.
} 
antara Halimah dan Aziz terjadi, Rois melabrak Tajul, seraya berkata, ini sama saja dengan merebut istri saya, ucapnya meniru perkataan Rois kala itu. ${ }^{34}$

Mulyono senada dengan apa yang dijelaskan Tajul, Halimah itu hanya diminta untuk membantu di rumah Rois bukan dilamar. Namun setelah mendengar Halimah sudah dipinang oleh orang lain, Rois marah karena ia menaruh cinta pada Halimah dan ingin mempersunting sebagai istrinya. Semenjak tahun 2009 itu, hubungan Rois dan Tajul semakin renggang. Ia keluar dari Shî‘ah dan kembali ke Sunnî. Pasca-geger itu, ia gencar menjelek-jelekkan kelompok Shî‘'ah yang dipimpin Tajul. Pada akhirnya Rois membentuk kelompok pengajian bernama "Ijtihad". Dalam kelompok pengajian ini, tokoh-tokoh yang hadir banyak dari kalangan bajingan (blater atau orang-orang jago).

Dalam setiap ceramahnya, Rois seringkali menytigma komunitas Muslim Shî‘ah yang dipimpin Tajul dan menyebarkan fitnah-fitnah kepada masyarakat. Ragam fitnah yang dieksplorasi terhadap komunitas Shî‘ah di bawah pimpinan Tajul itu seperti isu diperbolehkannya saling tukar istri, boleh kawin di mana saja tanpa harus ada saksi dan wali, alQur'ân mereka tidak sama, jemaah Shî‘ah mendapat tunjangan, dan sebagainya. Padahal menurut Mulyono, hal semacam itu tidak ada faktanya. Inilah yang sampai kepada masyarakat, padahal ketika mereka ditanya, mereka hanya menjawab "tidak ada yang dapat membuktikan faktanya". 35

Ummah, ibunda Tajul, ketika ditemui di Rusun Puspa Agro Sidoarjo, membenarkan konflik berdarah yang menjadi perhatian nasional itu, berawal dari konflik internal keluarga. Ia berusaha mendamaikan kedua putranya tersebut, namun tidak berhasil. Ia mengaku tidak pernah menduga konflik antara kedua anaknya itu bisa mengakibatkan bentrokan warga yang berlarut-larut. ${ }^{36}$ Iklil, seperti halnya sang ibu, mengaku tidak pernah menduga konflik antara kedua adiknya itu bisa mengakibatkan chaos yang besar. "Saya tidak menyangka, padahal dulu di keluarga kami tidak pernah ada masalah yang tidak terselesaikan dengan baik".

Menurut Iklil pula, semua yang menyebabkan perseteruan itu bermula ketika Rois merasa sakit hati kepada Tajul dan menyatakan diri keluar dari Shî‘ah. Padahal menurut Iklil, ketika masih berkeyakinan

\footnotetext{
34 Tajul Muluk, Wawancara, Sidoarjo, 12 April 2014.

35 Mulyono, Wawancara, Sampang, 20 April 2014.

36 Khairu Ummah, Wawancara, Sidoarjo, 12 April 2014.
} 
Shî‘ah, Rois yang paling getol berdakwah dan mengajak warga di sekitar untuk masuk paham Shi`ah. Namun, keadaan berubah setelah niat Rois untuk meminang Halimah gagal. Rois kecewa berat dan keluar dari Shî'ah, kemudian ia menganut paham Sunnî. "Sejak itulah konflik di keluarga kami tidak pernah bisa diselesaikan, ibu beberapa kali meminta saya mendamaikan Tajul dan Rois, tetapi hingga mereka dipertemukan di Polres Sampang pasca-bentrok 29 Desember 2011, perdamaian tidak tercapai". ${ }^{37}$

\section{Politisasi Kasus Sunnî-Shî‘ah di Sampang}

Konflik Sunnî-Shî‘ah Sampang Madura menjadi isu yang sensitif dan menjadi alat kepentingan berbagai kalangan, mulai dari tingkat akar rumput (grass root) sampai pada tingkat pusat. Dari sisi akar rumput, bisa dilihat pada kecemburuan sosial yang dialami Rois. Ia merasa keberadaannya dalam lingkaran kepemimpinan dan ketokohannya di kalangan kelompok Shî‘ah kurang memiliki peran, diperuncing lagi dengan masalah perempuan yang ingin dijadikan istrinya, tapi gagal. Rois mulai melakukan manuver-manuver untuk membangun dukungan dan mendongrak popularitasnya di tengah-tengah koomunitas Sunnî dengan membawa-bawa baju keyakinan agama demi memuluskan kepentingankepentinganya. ${ }^{38}$

Tendensi kekuasaan dan kepentingan menjadi bagian genosida dari kasus yang menimpa komunitas Muslim Shî‘ ah di Sampang Madura. Para kiai, membentuk semacam lingkaran kekuasaan kultural secara turuntemurun yang sudah terpatri bagi masyarakat Madura, sehingga setiap gejala sosial dan perubahan pandangan keagamaan yang berbeda dengan mainstream, ditafsirkan sebagai bentuk pembangkangan dan upaya meruntuhkan dominasi. Sasarannya adalah kalangan masyarakat yang tidak menikmati pendidikan formal dan berhati tulus. Mereka dengan mudah dijejali mitos-mitos supranatural, seperti karâmah, barâkah dan sebagainya. Harapan-harapan yang ditanamkan pada masyarakat tidak didasarkan pada parameter integritas dan kredibilitas.

Sosok Tajul yang tergambar elegan, ramah, suka membantu orang yang kurang mampu, hadir di kala dibutuhkan masyarakat tanpa harus diundang, tidak berkenan menerima honor (cabisan). Ia bertani dan berdagang sebagaimana masyarakat biasa, sehingga banyak warga yang

${ }^{37}$ Iklil Milal, W awancara, Sidoarjo, 12 April 2014.

38 Ibid. 
tertarik dengan kepribadian Tajul dan dakwahnya. Tiba-tiba persepsi publik berubah drastis karena dituduh sebagai pengganggu dan pembangkang terhadap feodalisme-religius, yang kalau tidak dieleminasi dengan segala macam cara akan menularkan kesadaran baru dan dikhawatirkan melahirkan sikap kritis serta dianggap mengganggu otoritas elite lokal yang selama ini mendominasi. ${ }^{39}$ Habermas menyatakan, konflik akan terjadi dalam kehidupan sosial, ketika integritas seseorang merasa terancam atau dilanggar oleh pihak lain. ${ }^{40}$

Damanhuri-seorang tokoh Sunnî yang moderat-menyatakan bahwa adanya konflik Sunnî-Shî‘ah itu menjadi keuntungan tersendiri bagi para kiai, karena kiai mudah memanfaatkan situasi dalam kesempitan walau tentu tidak semua kiai bersikap seperti itu. Kiai yang tidak ikut turut menyesatkan Shî'ah dikatakan di forum-forum pengajian sebagai orang yang turut mendorong adanya Shî'ah di Sampang, bahkan dicap sebagai Shî‘ah. Mereka memprovokasi agar tidak mengundang kiai tersebut dalam acara-acara pengajian, karena menurut mereka justru akan menyebarkan paham Shî‘ah secara diam-diam.

Bukan hanya itu, menurut Damanhuri, banyak kiai yang secara hati nuraninya tidak menerima terhadap tindakan kekerasan itu, tapi mereka harus memilih diam. Para kiai itu takut kehilangan karisma mereka dan berimplikasi pada berkurangnya santri di pesantren yang mereka asuh. Lalu mereka menjadi bagian dari konflik ini dengan mengiyakan labelisasi sesat terhadap kelompok Shî‘ah. Sangat tendensius karena mereka takut kehilangan aset-aset sosial-ekonomi mereka. ${ }^{41}$

Senada dengan informasi di atas, menurut Akh. Muzakki dalam pernyataannya di Jaringnews Surabaya, bahwa peristiwa kekerasan yang dialami komunitas Muslim Shî‘ah Sampang dinilai bukan murni karena perbedaan paham keyakinan keagamaan, tapi lebih karena kepentingan kuasa sosial dan politik kelompok. Muzakki mengatakan, Sunnî dan Shîah berbeda. Kasus Sampang itu lebih kental kepentingan kuasa sosial dan politike kelompok. Analisa sosiologis yang muncul dari kasus konflik Sunnî-Shî‘ah, bahwa perbedaan keyakinan hanya dipakai sebagai pemicu (triggering factor). Padahal penyebabnya sebenarnya adalah kontestasi kuasa sosial

39 Mulyono, Wawancara, Sampang, 20 April 2014.

40 Jenny Edkins dan Nick Vaughan Williams (eds.), Teori-teori Kritis Menantang Pandangan Utama Studi Politik International, terj. Teguh Wahyu Utomo (Yogyakarta: Pustaka Pelajar 2013), 251.

${ }^{41}$ Damanhuri, Wawancara, Sampang, 20 April 2014. 
politik antar-keluarga dan kelompok sosial. Perbedaan keyakinan seakanakan menjadi latar konflik Sunnî-Shî‘ah di Sampang. Kasus ini mengantarkan pada simpulan, agama hanya kerap dimanfaatkan untuk memompa emosi masyarakat. Sebab isu agama merupakan instrumen yang paling mudah untuk memobilisasi sentimen massa.

Ifdhal Kasim, Ketua Komisi Nasional Hak Asasi Manusia, sebagaimana dilansir koran Tempo menyatakan bahwa, Faktor agama memang salah satu pemicu, tetapi persaingan politik pemilukada juga ikut berpengaruh dalam mempertajam isu Shî‘ah-Sunnî yang mulai hidup. Komnas HAM menilai pemerintah Kabupaten Sampang tidak dapat berbuat banyak untuk mengatasi konflik ini, karena isu Sunnî-Shî‘ah sudah diangkat oleh kontestan dalam pemilihan kepala daerah pada periode sebelumnya dan dimanfaatkan untuk memperoleh dukungan politik. Oleh Karena itu, Bupati Sampang tidak banyak berperan dalam penyelesaian konflik ini, bahkan menawarkan relokasi. Hal senada juga dikatakan oleh Komisioner Komnas Perempuan, Husein Mohammad bahwa konflik agama hanyalah kendaraan untuk membentuk sikap politik publik. Kebanyakan konflik serupa muncul menjelang pemilihan atau peristiwa politik dan sejenisnya. ${ }^{42}$

Banyak pernyataan yang menegaskan akan aroma politisasi dan kepentingan pada kasus konflik antara Muslim Shî‘ah dan Sunnî di Desa Karang Gayam dan Blu'uran dengan bermacam analisa terhadap fakta, sehingga sulit diurai simpul kusut di dalamnya untuk menemukan pembuktian mana yang benar dan yang salah. Simpulan yang dapat diambil sementara, bahwa selain aspek politik, pendidikan adalah indikator lain yang memicu meletusnya konflik ini. Selain itu, kemiskinan dan berbagai bentuk kemelaratan yang dialami oleh masyarakat Sampang, membuat kesenjangan sosial dan berakhir terjadinya kekerasan. Kemiskinan dan kemalaratan itu tidak saja karena kondisi sistem ekologis-pertanian, tegalan-yang tidak memberikan keuntungan ekonomis semata, tetapi juga diakibatkan karena struktur dan bangunan kekuasaan yang tidak mempedulikan kondisi perbaikan hidup masyarakat banyak, karena lebih mementingkan pada kelompok dan golongan masing-masing.

42 Anggrita Desyani, "Komnas HAM: Konflik Syiah Sampang Berbau Politik", dalam http://www.tempo.co, Jakarta (9 Sebtember 2012). 
Sejarah mencatat bahwa masyarakat Madura semenjak dulu mengalami eksploitasi oleh 'kekuasaan kembar' (twin-regimes), yakni para kaum aristokrat-ningrat yang menjalankan birokrasi kekuasaan dengan berkolaborasi dengan kekuasaan Belanda yang tidak saja memeras secara ekonomi, fisik, dan mentalitas masyarakat. Proses kapitalisasi yang berlangsung di Madura semakin memarginalisir penduduk setempat. Dengan demikian munculnya tindakan kekerasan secara umum dapat disimpulkan sangat terkait dengan struktur ekologis dan gerak sosiologis masyarakat dalam merespons kondisi sosial yang dihadapinya, seperti keterjepitan ekonomi dan kapitalisasi pembangunan yang tidak memberdayakan masyarakat kecil, atau kelas menengah ke bawah. ${ }^{43}$

Pada dasarnya manusia menginginkan kehidupan yang harmonis, namun karena struktur sosial ekonomi yang melingkupi kehidupan manusia, terutama ketika kebutuhan dasar manusia yang ia perlukan tidak terpenuhi di mana hal ini memicu terjadinya konflik. Pola relasi yang tidak seimbang dalam proses sosial antarindividu kerap melahirkan gesekan kepentingan yang melahirkan disharmoni dan berujung konflik horizontal. Dengan demikian dapat dikatakan, konflik merupakan bagian dari proses perubahan sosial yang lahir karena adanya heterogenitas kepentingan, seperti kepentingan nilai-nilai keyakinan. Oleh karena itu, Liliweri memahami konfilik sebagai bentuk pertentangan alamiah yang dihasilkan oleh individu atau kelompok, karena mereka yang terlibat memiliki perbedaan sikap, kepercayaan, nilai dan kebutuhan. ${ }^{44}$

\section{Konsekuensi Modalitas dari Kasus Sunnî-Shî‘ah}

Konflik sebenarnya tidak perlu dianggap sebagai peristiwa atau fenomena yang menyebabkan kekerasan. Konflik merupakan realitas konkret dalam interaksi sosial, tanpa mengabaikan akibat negatif yang menyebabkan terpecahnya ikatan sosial. Konflik bisa saja menjadi pendorong untuk perubahan sistematis dalam jangka panjang dan membangun hubungan yang kondusif dan harmonis. Konflik mempunyai potensi untuk menjadi pengaruh yang bermanfaat atau merugikan, tergantung bagaimana cara menyalurkan konflik tersebut. Transformasi konflik terjadi kalau konflik terinstitusionalisasi, baik dalam NGO (Non-Gavernment Organization), partai politik, tokoh-tokoh agama,

43 Wiyata, Carok: Konflik Kekerasan, 71.

44 Alo Liliweri, Prasangka dan Konflik: Komunikasi Lintas Budaya Masyarakat Multi Kultural (Yogyakarta: LKiS, 2005), 249. 
tokoh-tokoh masyarakat, dan lain-lain. Akibat dari proses damai ini akan menimbulkan energi konstruktif untuk suatu perubahan positif, namun jika konflik tidak terinstitusionalisir dengan baik, bisa mengarah pada kekerasan yang destruktif dan menghasilkan polarisasi di antara yang kalah dan menang.

Dalam ilmu sosiologi, konflik merupakan fenomena sosial yang bersifat umum. Weber menyatakan konflik tidak dapat disingkirkan dari kehidupan sosial, sebab perdamaian tidak lebih dari sekedar merubah bentuk konflik atau mengubah objek konflik yang pada akhirnya mengubah ke bentuk kesepakatan-kesepakatan bersama atau kedamaian. Simmel juga mengatakan konflik merupakan bentuk kehidupan sosial dan sejumlah perbedaan, pertentangan intern serta kontroversi ekstern secara struktural terkait dengan elemen-elemen, yang pada akhirnya mengarah pada ikatan bersama dalam kelompok.

Dampak konflik pada struktur sosial bervariasi bergantung pada tipe struktur sosial masyarakat itu sendiri. Dalam struktur masyarakat yang longgar, pluralistik, dan terbuka, perbedaan pandangan dapat menyelesaikan kerasnya konflik antara dua pihak yang bersebarangan dan berfungsi menstabilitaskan struktur. Oleh karena itu, jika pihak-pihak yang berseberangan diberi kesempatan yang berimbang dalam menyampaikan wawasanya, maka konflik itu, membantu menghilangkan sebab-sebab terjadinya perpecahan dan mengarah pada terciptanya stabilitas kehidupan yang harmonis. ${ }^{45}$

Apapun bentuk benturan sosial yang berlangsung akibat konflik sosial, konsekuensinya akan selalu sama, yaitu tekanan sosial, kepedihan, disintegrasi sosial dan disertai juga oleh musnahnya aneka aset-aset material dan non-material. Kehancuran aset-aset non-material yang paling kentara ditemukan dalam wujud dekapitalisasi moral sosial yang ditandai oleh hilangnya trust (kepercayaan) di antara para pihak-pihak yang bertikai, rusaknya networking dan hilangnya compliance (ketaatan) pada aturan norma dan tatanan sosial yang telah disepakati bersama-sama. Seolah semua aturan norma dan tatanan sosial yang telah dibangun dan ditegakkan dengan susah payah serta dijadikan kesepakatan untuk menjalani hidup bersama dengan rukun dan damai oleh masing-masing

45 A. Khozin Afandi, Langkah Praktis Merancang Proposal (Surabaya: Pustakamas, 2011), 98-99. 
warga yang bertikai, dengan mudah diakhiri begitu saja karena konflik sosial.

Pembakaran rumah Tajul yang berakhir dengan pengusiran beserta jemaahnya menyisakan kepedihan, sakit hati, dendam, dan trauma yang mendalam terutama pada perempuan dan anak-anak. Secara budaya, konflik Sunnî-Shî'ah dipicu oleh perbedaan cara berdakwah, yang kemudian menggunakan kendaraan perbedaan keyakinan, sehingga memicu ketegangan di masyarakat. Tajul dengan sikapnya yang egaliter, supel, ringan tangan, cekatan dan tidak menerima honor (cabisan) di setiap ceramahnya serta mendesain perayaan Maulid Nabi Muhammad dengan cara disatukan di masjid untuk mengurangi beban warga, namun hal ini, di sisi lain menimbulkan kecemburuan sosial pada kiai lain di sekitarnya.

Absennya mekanisme dialog di masyarakat sering membuat prasangka dan kecemburuan mengristal dan pecah menjadi kekerasan yang merusak semua tatanan masyarakat. Tidak terkecuali tatanan budaya bhala (persaudaraan) yang sudah mapan di Madura. Penyerangan pemukiman komunitas Muslim Shî‘ah bukan saja telah menghancurkan harta benda dan dan fasilitas publik, namun, juga telah mengoyak tatanan budaya masyarakat Madura. Persaudaraan pecah karena berebut klaim kebenaran. Kepatuhan kepada orang tua seperti tercermin dalam bhuppa' bhabu', ghuru, rato, runtuh karena dipaksa harus berpihak pada apa yang dianggap benar. Hilang sudah taretan dhibi' atau taretan dalem (saudara sendiri) yang menjadi simbol keakraban dan kesolidan orang Madura. Ikatan etnisitas sejak lahir harus kalah dengan kepentingan untuk mendapatkan klaim 'paling benar'. Terkubur sudah harmoni dengan sesama manusia.

Konflik Sunnî-Shî‘ah yang terjadi di Sampang Madura secara langsung telah merusak sistem nilai yang sudah tertanam kokoh dan indah. Puluhan tahun bahkan sudah ratusan tahun nilai-nilai itu mampu menjalin masyarakat Madura hidup rukun damai dan harmonis. Entah kenapa sistem nilai yang sudah menjadi pedoman ratusan tahun dalam kehidupan masyarakat Madura akhirnya pecah menjadi konflik SunnîShî'ah Sampang Madura. Ini telah merusak nilai-nilai dan tradisi-tradisi, khususnya nilai-nilai toleransi dan pluralisme serta mekanisme penyelesaian konflik berdasarkan tradisi lokal, yang disebut dengan taretan atau bhala (saudara). 
Konflik Sunnî-Shî‘ah Sampang Madura di samping merusak sistem tata nilai ke-madura-an juga dapat menyebabkan hilangnya hubungan persaudaraan atau keluarga. Para pengikut Shî‘ ah yang mengungsi banyak yang memiliki hubungan sanak keluarga di kampung halamannya, yang tidak mengikuti paham Shî‘ah. Dengan keadaan mereka yang hidup di pengungsian hubungan mereka terputus. Kondisi itu menyebabkan terputusnya hubungan keluarga bagi kelompok Shî‘ah.

Sementara kekerasan, apapun bentuknya, tidak layak dipertontonkan ke publik terutama di depan anak-anak, namun yang terjadi di Sampang. Para bocah yang masih duduk di bangku sekolah justru ikut menjadi korban serangan massa intoleran tersebut. Hal ini tentu memprihatinkan. Anak-anak yang menjadi korban kekerasan sudah pasti mengalami trauma yang mendalam. Bukan tidak mungkin hal itu menimbulkan dendam di hati mereka. Anak-anak warga Shî'ah korban peristiwa penyerangan, dalam hal ini, tidak bisa dikatakan bebas dari kondisi tekanan, dendam dan trauma yang menjadi umum sebagai dampak konflik.

Dampak lainnya adalah kaum Shî‘ah juga tidak lagi bebas menjalankan ibadah sesuai dengan keyakinannya. Kaum Shî‘ah hidup dalam kecemasan dan ketakutan karena terus mengalami intimidasi dan khawatir jika penyerangan serupa terulang. Kebebasan mereka juga terpasung dan tidak bisa berkembang karena selalu diawasi. Tentu dampak ini sangat kontraproduktif dengan sistem bernegara yang sedang diperjuangkan di Indonesia. Pancasila dan UUD 1945 masih belum mengakar dan terinternalisir ke dalam diri individu untuk memerankan peranannya dalam berbangsa dan bernegara. Apa yang terjadi dari konflik Sunnî-Shî‘ah menjadi bukti keraguan ini.

Dengan demikian, jelas betapa besarnya dampak yang ditimbulkan konflik Sampang. Selain menyebabkan kerugian material yang sangat besar, juga mengakibatkan aspek-aspek kemanusiaan yang seharusnya dijaga menjadi runtuh berpuing-puing. Hubungan kekerabatan dan persaudaraan sesama umat Muslim serta persaudaraan sesama etnik Madura kini hanya pemanis bibir. Kebebasan, informasi, pendidikan, kelayakan hidup, hingga perlakuan adil bagi sesama manusia hanya visi yang tak terwujud. Selain dampak yang sudah ditulis, tentu masih banyak yang belum teridentifikasi dari konflik Sunnî-Shî‘ah di Sampang. Jika 
tidak segera mendapat penanganan serius, bukan tidak mungkin akan terjadi konflik lebih dahsyat lagi mendatang.

Kondisi sosial ekonomi masyarakat jemaah Shî‘ah masuk kategori jauh dari standar hidup layak dan sejahtera. Masyarakat yang terlibat konflik Sunnî-Shî'ah dikategorikan sebagai miskin, berpendidikan rendah, dan jauh dari infrastruktur yang kurang memadai. Komunitas Muslim Shî'ah sebagai subjek konflik, yang sebelumnya miskin dan tidak berdaya secara ekonomi, dengan konflik itu semakin menguatkan dan memperpanjang rentan kemiskinan di antara individu dalam kelompok ini. Lebih-lebih mereka harus berada di pengasingan dengan tanpa memiliki modal terhadap akses ekonomi. Tentu kondisi ini semakin mempersulit mereka.

Konflik telah menyebabkan mereka kehilangan mata pencaharian. sehingga mengganggu dan memperparah kelangsungan dan kualitas hidup mereka. Para penganut Shî‘ah yang kesemuanya adalah petani, akibat pengusiran dari lahan ekonomi yang menjadi keahlian mereka, yakni bertani, kini di pengungsian harus kehilangan modal keahlian ekonomi mereka. Kemampuan bertani untuk menyambung hidup harus berhenti seketika. Aktivitas sehari-hari yang sudah menjadi rutinitas dari kelompok ini terhenti dan terganti. Mereka hanya menunnggu uluran tangan para dermawan dan bantuan pemerintah untuk bisa bertahan hidup. Hal ini jelas menambah panjang rentetan kemiskinan para penganut Shì'ah yang notabene warga resmi di Indonesia dan terlindungi hak hidupnya oleh undang-undang yang berlaku.

\section{Catatan Akhir}

Konflik Sunnî-Shî‘ah yang terjadi di Sampang disebabkan serangkaian wacana kebencian dan penyesatan yang terus dilakukan secara intens oleh para elite lokal terhadap komunitas Muslim Shî‘ah yang dipimpin Kiai Tajul. Motif perseteruan internal keluarga antara Tajul dengan Rois yang disebabkan oleh faktor kecemburuan sosial dan asmara serta fatwa sesat MUI se-Madura dan tingkat Provinsi Jawa Timur terhadap komunitas Shî‘ah ini semakin memperkeruh dan mengarahkan ke konflik horizontal yang besar dan berdampak sistemik. Konflik ini menjadi tragedi berdarah dan lebih disebabkan oleh akumulasi persoalan di lingkup lokal, regional, bahkan nasional, se hingga eskalasi konflik semakin memanas dan berlarut-larut tidak kunjung selesai. Hal ini menjadi bukti bahwa sistem kepemimpinan patron 
mengambil bagiannya dalam mengarahkan ke bentuk konflik. Sekaligus menjadi pemahaman umum bahwa setiap konflik, apalagi yang berujung pada kekerasan selalu mengakibatkan dampak-dampak sosial yang merubah tatanan sosial-budaya yang sudah mapan, baik dalam kehidupan beragama maupun dalam interaksi sosial kemasyarakatan.

\section{Daftar Rujukan}

Afandi, A. Khozin. Langkah Praktis Merancang Proposal. Surabaya: Pustakamas, 2011.

Chalik, Abdul. "Kiai dan Kekuasaan Sosial dalam Masyarakat Madura", Jurnal Paramedia, Vol. 10, No. 1, 2010.

Damanhuri. Wawancara. Sampang, 20 April 2014.

Desyani, Anggrita. "Komnas HAM: Konflik Syiah Sampang Berbau Politik", dalam http://www.tempo.co, Jakarta 9 Sebtember 2012.

Edkins, Jenny dan Williams, Nick Vaughan (eds.). Teori-teori Kritis Menantang Pandangan Utama Studi Politik International, terj. Teguh Wahyu Utomo. Yogyakarta: Pustaka Pelajar 2013.

Husaini, Adian (ed.). Kritik dan Solusi Syiah di Indonesia. Depok: Adabi Press, 2012.

Indonesia, Tim Penulis Majlis Ulama. Mengenal dan Mewaspadai Penyimpangan Syiah di Indonesia. Jakarta: FORMAS, 2013.

Jabali, Fuad. "Sengketa Iman", dalam Mata Najwa Metro-TV 5 September 2013.

Jonge, Huub De. Garam, Kekerasan, dan Aduan Sapi:Esai-esai tentang Orang Madura dan Kebudayaan Madura. Yogyakarta: LKiS, 2011.

Liliweri, Alo. Prasangka dan Konflik: Komunikasi Lintas Budaya Masyarakat Multi Kultural. Yogyakarta: LKiS, 2005.

Mathari, Rusdi. "Mereka Sibuk Menghitung Langkah Ayam", dalam http://rusdimathari. wordpress.com/2012/08/27/mereka-sibukmenghitung-langkah-ayam-reprtase-kasus-syiah-sampan g/. Agustus 2012.

Mawuntyas, Dini. "Bagaimana Kronologi Syiah Masuk Sampang?", dalam http://www. tempo.co, Surabaya 2 September 2012.

Milal, Iklil. Wawancara. Sidoarjo, 12 April 2014.

Muluk, Tajul. Wawancara. Sidoarjo, 12 April 2014.

Mulyono. Wawancara. Sampang, 20 April 2014.

Pizaro, "Tajul Muluk dan Kisah Ingkar Janji Syiah Sampang", dalam http://www.islampos.com (21 Juni 2013). 
Rozaki, Abdur. "The Social Origins and Political Power of Blaters (thugs) in Madura", dalam http://kyotoreview.org/wp-content/uploads /Abdur-Rozaki-ENG.pdf./11 Desember 2009.

Rukmorini, Regina. "Kerusuhan Temanggung, Tiga Gereja Dirusak Massa", Kompas 8 Februari 2011.

Silalahi, Levi. "Poso, Enam Tahun Dirundung Duka", Tempo 12 Mei 2004.

Soebijoto, Hertanto. "Inilah Kronologi Cikeusik Berdarah itu”, Kompas 26 April 2011.

Sudjangi. "Konflik Sosial Bernuansa Agama: Studi Kasus Kerusuhan di Ambon", dalam http://balitbangdiklat.kemenag.go.id. Departemen Agama RI 2002.

Ummah, Khairu. Wawancara. Sidoarjo, 12 April 2014.

Waidi, Cholis. Wawancara. Sampang 5 Maret 2014.

Wiyata, A. Latief. Carok: Konflik Kekerasan dan Harga Diri Orang Madura. Yogyakarta: LKiS, 2002. 